Pro-Fil 22 (2) 2021: 68-77

https://doi.org/10.5817/pf21-2-2457

\title{
FILOSOFIE IRONIE KARLA WILHELMA FERDINANDA SOLGERA
}

\author{
BŘETISLAV HORYNA ${ }^{1}$ \\ Katedra filozofie, Filozofická fakulta, Univerzita Konštantína Filozofa, Nitra, \\ Slovenská republika, bhoryna@ukf.sk \\ PŘEKLAD S KOMENTÁŘEM
}

\begin{abstract}
Jedním z mála racionálních způsobů, jak přesáhnout vše, co může být vyjádřeno v pojmech, a jak nechat za sebou sám výraz nezbytný k vyjádření, je ironie. Pro filosofii je ironie královské a úměrně své aristokratičnosti vrcholně nevděčné téma. Uzavírá se jakémukoli pojmovému výrazu, není redukovatelná na slovo a termín, ale současně požaduje, aby jí náleželo maximum reflexe, bystrého vědomí, které se prodírá co nejhlouběji k jejím kořenům, k myšlení, jež je tím, o čem nevypovídá, a vypovídá o tom, čím není; přitom se však dokáže vypořádat se závratností přicházející spolu se zjištěním, že ironie vždy uniká logickým schématům, požadavkům na pravidla vnímání (aisthesis) a nejčilejší je tam, kde je vrcholně nevítaná - v sulcovitě roztřesené existenciální bázni o autenticitu vlastního života. Ironie je sama svou estetikou, svým poznáním, které stojí bok po boku s pochybností, s níž se nepojí žádné další zájmy. Mohou být spolu (a často jim nic jiného nezbývá, protože opak by byl nesnesitelný), poněvadž nejsou nuceny mít pravdu, vyjádřit pravdu, být pravdou, nemusí prolamovat mlčení o věcech a o tom, jaké jsou, ani si nekladou závazek účasti na tvorbě stále lepší lidské pospolitosti, brigád na ustavení kolektivů dobra, radosti a krásy.
\end{abstract}

Pochybnost spojenou s ironií lze unést, protože není dodatečnou, ale naopak je původní zátěží. Nic nepřidává, nýbrž pomáhá omezit nebo úplně eliminovat tendence k sebevyjádření a kompenzuje jejich neodbytnost agnostickým stažením z agory, z pódia, $\mathrm{z}$ manéže, $\mathrm{z}$ tribuny, $\mathrm{z}$ kazatelny a z dalších míst, kde se „děje bytí podle svého smyslu a pravdy“. Co se naopak snášet nedá a co vždy přesáhne meze, včetně a snad i především ty fyziologické, které v sobě má živý člověk, je bolest, z níž pobratimství ironie a skepse vůbec vyrůstá. Ironie ničí všechny metafyzické iluze, zatahuje oponu za tragickými hrdiny, spojuje se se sarkasmem a s cynismem, aby ukázala, že neexistuje nic z těch naléhavostí, niterností, nevyhnutelností a pravostí, kvůli nimž se dějiny vlečou jako řeky zakrvavené špíny. Avšak jako všechno, co se zrodilo a zase zaniklo v lidských společenstvích, i ona v něčem selhává: rozbíjí se o neschopnost udržet si odstup od toho, co sama ironicky rozkládá, a nedostatek distancovanosti z ní činí sobě důvěřující opravdovost. Ironie si klade podmínky a neumí je ironicky dodržet; ironik musí být homo distans, jehož postoj v sobě obnáší schopnost trvalého snášení bolesti ze světa, nekončící Weltschmerz, jež neustane, dokud si lidé budou bližní.

Už jenom proto je takový požadavek nelidský, pochází odněkud, kam člověk nedosáhne a odkud si nevezme nic z toho, co musí mít, aby mohl být doslovně ironikem: nezdarem prošel kdysi Fr. Schlegel jako dnes O. Marquard, kdysi Fr. Nietzsche jako dnes P. Sloterdijk. Ironie je k mání jako torzo, jako neúplnost a zlomek, jako roztroušenost a nehotový podíl na sobě samé, jako odštěpek z lomného pazourku: kdo uvěří v její absolutní převahu, toho oslepí. Lidé se cítí

\footnotetext{
${ }^{1}$ https://orcid.org/0000-0002-6610-246X
} 
důstojněji, když slepnou v pravdě a oslepují kvůli pravdě, než když - na závěr a zcela lidsky neobstojí před bolestí světa a selhávají (také či dokonce) ve své ironii; nechce-li člověk dozrát v megalomana, měl by si uhájit odstup rovněž od vlastní důstojnosti. Ironie si tak stále vyžaduje celého člověka, ale pro něho není celá nikdy, stále zůstává nevyřčená.

S takovou, svým založením protreptickou ironií plnou aporetických nabádavých fragmentů, se setkal také jeden z dnes opomíjených filosofů epochy německého idealismu, Karl Wilhelm Ferdinand Solger, představitel estetizovaného raného romantismu, bez nějž by byla romantická teorie ironie výrazně ochuzená.

\section{Romantická teorie ironie}

Karl Solger ${ }^{2}$ patř́ $\mathrm{k}$ těm postavám německých dějin filosofie, o kterých se tu a tam objeví úctyplná poznámka pod čarou, aniž by její autor měl důkladnější představu, proč je vlastně jeho poznámka úctyplná. Solger se tímto způsobem traduje a přechází z knihy do knihy, z biografie do biografie, z encyklopedie do encyklopedie, poněvadž má zásluhu o cosi významného. Dostává se mu hesla, které toho př́liš neříká, nejméně o jeho filosofii. V literární teorii ho znají nejlépe jako př́tele básníka Johanna Ludwiga Tiecka, s nímž vedl rozpravy o umění, německá translatologie na něj občas vzpomene jako na tvưrce romantické teorie překladu, jejíž hlavní teze přisuzuje překlad jako autonomní úlohu filologii, podřizuje ho prostředkům filologie a trvá, jak je patrné na Solgerových překladech Sófoklových tragédií, na zachování všech dobových zvláštností překládaných děl.

Ucelené vyjádření obsahu a zhodnocení významu Solgerova díla je poměrně složité z několika důvodů. Především zanechal velmi málo ucelených textů; zemřel náhle v devětatřiceti letech (údajně na nervovou horečku) a jeho dokončené spisy, tzn. Erwin a Filosofické rozhovory, toho nevypovídají zdaleka tolik, kolik posthum sestavené a vydané Pozůstalostni spisy a korespondence, jež vznikly zásluhou básníka J. L. Tiecka. Jsou důležité, protože podávají poněkud odlišný obrázek Solgerovy filosofie: po jejich prostudování by čtenář byl zřejmě ochoten zařadit Solgera k německým autorům ovlivněným především Fichtem a Schellingem, kteří se pokoušeli domýšlet systémy německého idealismu nad jejich pojmovými limity a vyhýbali se přitom přímému střetu s kypícím hegelovstvím. Jistě by bylo oprávněné spojovat Solgera také s rozvojem státoprávních teorií; tendence k nim byla živá hlavně od konce 17. a po celé 18. století,

\footnotetext{
${ }^{2}$ Karl Wilhelm Ferdinand Solger (1780-1819) se narodil ve Schwedtu (Braniborsko) v rodině úředníka. Po maturitě na gymnasiu v Grauen Kloster studoval v Halle práva a klasickou filologii (1798-1801) a v Jeně navštěvoval Schellingovy přednášky. Z existenčních důvodů nastoupil do státních služeb, úřednickou práci ale v roce 1804 zase opustil a pokračoval ve studiích u J. G. Fichta, kde se seznámil s jeho Vědoslovím. Promoval roku 1808 v klasické filologii překlady Sófoklových tragédií a od roku 1809 byl povolán na univerzitu ve Frankfurtu nad Odrou. Za další dva roky přešel do Berlína na nově založenou Humboldtovu univerzitu, kde spolupracoval s Fichtem, Schleiermacherem a zejména s Hegelem, o jehož povolání do Berlína se jakožto rektor (1814-1815) významně zasloužil. Přednášel filosofii práva, metafyziku, logiku, ale hlavní zájem spočíval v estetice. Jí patř́i také jeho jediná dokončená díla, čtyřdílný dialog Erwin. Vier Gespräche über das Schöne und die Kunst (Berlin 1815, 2 Bde) a Philosophische Gespräche (Berlin 1817). Nejvíce poznatků o jeho koncepcích a teoriích však poskytuje velký soubor nedokončených textů, náčrtů, poznámek a korespondence, který vyšel pod názvem Nachgelassenen Schriften und Briefwechsel v Lipsku roku 1836 péčí J. L. Tiecka a Fr. Raumera. Posthum vyšla Solgerova nejznámější práce Vorlesungen über Ästhetik, kterou k vydání připravil jeho bývalý student Karl Wilhelm Ludwig Heyse (Berlin, 1829). Solger zemřel náhle roku 1819. Za jeho života ho více než filosofie proslavily překlady Sófoklových tragédií (Krále Oidipa vydal poprvé anonymně již roku 1804, souborné vydání s více než stostránkovou předmluvou vyšlo1808 v Berlíně pod titulem Des Sophocles Tragödien), které vysoce ocenila odborná veřejnost, jmenovitě např. Goethe. K teorii romantické ironie, která se skrývá zejména v Solgerově korespondenci s Tieckem, bylo následně a ne zcela oprávněně přiřazeno pouze jméno Friedricha Schlegela.
} 
za Solgerova života doznívala a přecházela stále zřetelněji do „filosofie práva“, jejímž vrcholným ztvárněním je Hegelova Rechtsphilosophie, ${ }^{3}$ dokončená a publikovaná těsně po Solgerově úmrtí. V Tieckově korpusu je možné částečně se seznámit také s estetickými Solgerovými náhledy, avšak na mnohem menším prostoru než dostává třeba jeho filosofie náboženství, filosofie mytologie a filosofická esejistika. ${ }^{4}$ Poněkud paradoxně se v tomto souboru neobjevuje téma ironie, díky němuž jméno tohoto filosofa nezapadlo již zcela.

Spekulace o důvodech tohoto opomenutí, jež zřejmě nebylo úplně mimovolné, nepřinesou nic zásadního. Tieck a Raumer představili Solgera v té perspektivě, v které ho zejména Tieck dobře znal, a v té se ironie skrývá spíš mezi estetickými a kunsthistorickými nástroji; uvažuje se o ní jako o prvku kompozice uměleckého díla, pokud je jím německý Lustspiel: ani komedie, ani veselohra, ani klauniáda, buffonerie nebo šprýmování, ale spíš vtip, kterým se dá ř́íci hodně neveselých věcí. Lustspiel je rozesmátá hořkost poznání, přes kterou se člověk musí - aby mohl přežít jinde než na soustavném útěku odnikud nikam - přenést k obyčejnému, zvykovému, chápajícímu životu. Způsob tohoto přenášení mu ukazuje ironie. Všechny tyto souvislosti s jejich četnými a občas i značně nesnadnými přesahy do filosofie byly z Tieckova pohledu dostatečně zpracované básníky a filosofy řazenými k rané romantice, především Fr. Schlegelem. Navíc tu byl Hegel a jeho až nemístně tvrdý odsudek dle něj prázdné, jalové a zbabělé romantické ironie, po kterém Tieck zrrejmě nechtěl speciálně upozorňovat na Solgerovu ironickou tezi. Svou roli mohly sehrát rovněž osobní vztahy Solgera a Hegela; Hegel byl Solgerovi svým způsobem zavázán za profesuru na berlínské univerzitě, ale bližší osobní nebo profesní vztahy mezi nimi nevznikly. Solger chtěl dostat Hegela do Berlína kvưli jeho géniovi, ne proto, aby se s ním spřátelil, což se také nikdy nestalo, přestože některé Solgerovy texty jeví př́i vnějším pohledu určitou, zejména pojmovou podobnost s Phänomenologie des Geistes a dalšími ranými texty. ${ }^{5}$ Tyto aspekty je patrně možné prričítat rozhodnutí vykreslit v Pozůstalostních spisech Solgerův obraz s důrazem na jiné než ironické momenty.

Samotný Hegel Solgera až pozoruhodně uznával a respektoval; zmínil ho v Rechtsphilosophie 6 a v Ästhetik, za vlastní vyrovnání s ním lze ale považovat spíše až Hegelovu podrobnou recenzi Tieckova a Raumerova dvoudílného sborníku Solgerových statí, zveřejněnou v Jahrbüchern

\footnotetext{
${ }^{3}$ Hegel, G. W. F. (1820). Grundlinien der Philosophie des Rechts. Naturrecht und Staatswissenschaft im Grundrisse. Berlin: Nicolai.

${ }^{4}$ Solgerovy úvahy a eseje, at' již určené k publikaci nebo mnohem častěji obsažené v dopisech, se nejčastěji stáčejí k otázce „,nedorozumění nad filosofií“ (Mißverständnisse über Philosophie): kromě toho, že zde najdeme mnohé $\mathrm{z}$ toho, co rezonuje v současné filosofii, bych nacházel právě v těchto s nadhledem a nutným odstupem psaných textech právě toho Solgera ironika, o kterém se uvažuje spíš v souvislosti s romantickým konceptem ironie.

${ }^{5}$ Solger to jistě pocit’oval a také se postavil proti případným nařčením z plagiátorství. V dopise adresovaném Tieckovi z 26. dubna 1818 napsal o Hegelovi: In der Dialektik haben wir beide unabhängig von einander fast denselben Weg genommen (,v dialektice jsme oba nezávisle na sobě zvolili téměř tutéž cestu“).

${ }^{6}$ Vyhlášený je v tomto ohledu $§ 140$. Zde shromáždil Hegel snad všechna negativa, která byl schopen na ironii najít, včetně určení ironie jako „zla“, „pokrytectví“, „přetvářky“, apod., většinou ve spojení s Fr. Schlegelem a Schleiermacherem. Odtud také pochází základní rozlišení mezi platónskou (sókratovskou) ironií, jež je tolerována, protože se vztahuje pouze k osobám podílejícím se na dialogu, nikdy se ale netýká ,zlehčení“ ideje samotné. Že by mohla být idea ztotožněna s ironií a ta pochopena jako to „poslední“ či „,substanciální“, bylo pro Hegela nepředstavitelné znevážení spekulativní filosofie. „Nedávno zemřelý kolega“, jak se zde mluví o Solgerovi, je odsouzen víceméně podmínečně kvůli svému lepšímu smyslu pro filosofii. Hegelovo vynětí Solgera $\mathrm{z}$ hromadného odsudku je zvláštní i v souvislosti jednoho z posledních Solgerových vyjádření k ironii, kde napsal: „Pravá ironie vychází ze stanoviska, že člověk, dokud žije v tomto prŕítomném světě, může naplnit své určení dokonce i v nejvyšším slova smyslu pouze v tomto světě. Všechno, co považujeme za prekonáni konečných účelů, je planá a prázdná domýšlivost“ (in Nachgelassene Schriften, sv. 2, 514-515; „Die wahre Ironie geht von dem Gesichtspunkt aus, daß der Mensch, solange er in dieser gegenwärtigen Welt lebt, seine Bestimmung auch in dem höchsten Sinne des Wortes, nur in dieser Welt erfüllen kann. Alles, womit wir über endliche Zwecke hinauszugehen glauben, ist eitle und leere Einbildung").
} 
für wissenschaftliche Kritik roku 1828. Z ní vyplynuly dvě teze, jež získaly určující postavení při obecném začlenění Solgerovy filosofie do dějin německého idealismu: první, která říká, že recenzovaný korpus poskytuje mnohem přesnější a určitější představu o základních Solgerových názorech než díla, která vydal za svého života, a druhá, podle níž zastával Solger princip ironie jako systematizující, „pořádající“ ideu romantické teorie a není proto srovnatelný se Schlegelovou koncepcí. Je patrné, že Hegel si cíleně vybral Solgera pozůstalostních spisů a vytvořil postavu autora s vlastním místem mezi spekulativními filosofy s talentem pro umění, literaturu, s polemicky odmítavým vztahem vůči vnějšímu prostředí, v němž působil, a s dostatečně silným zakotvením v klasické vzdělanosti, aby nepropadl extrémům romantického nevkusu, tak typickým pro Schlegela, Novalise nebo Tiecka.

Nakolik je Hegelovo odpoutání Solgera od romantické ironie ve shodě s jeho filosofií (či spíše s tím zlomkem jeho patrně poměrně rozmáchlých hledisek a názorů, jež předložili zájemcům Tieck a Raumer v upraveném a zušlechtěném souboru pozůstalostních spisů) a nakolik působily v jeho myšlení dostatečně silné odstředivé síly, které by mu bránily akceptovat zejména fichtovskou systematiku transcendentální ideje, je nutné rozhodnout samostatným studiem Solgerových prací. V nepř́liš rozsáhlé sekundární literatuře lze najít apologetiky obou těchto hledisek i další s nimi nesouvislé interpretace, které usilují o autonomní výklad solgerovské ironie. ${ }^{8}$ Do začátku lze uvést, že Solger zřejmě nebyl „systematikem romantické ideje“, za kterého ho chtěly mít některé starší interpretace 9 : i kdyby se vyjasnilo, co se myslí dotyčnou ,romantickou ideou“, Solgerovi by systematizaci poetologicky laděné raně romantické symfilosofie nedovolovala jeho schellingovská a fichtovská východiska. Už vůbec nebyl apoštolem ironie obětovaným Hegelově systému, jak tvrdí pod Kierkegaardovým vlivem Jan Steward ${ }^{10}$ : sporné je jak jeho apoštolství, tak vydanost Hegelovu systému, s kterým neměl žádnou zásadnější zkušenost.

Následující překlad byl vybrán cíleně, aby ukázal polohu, v níž Solger filosoficky vynikal: pojmová průprava $\mathrm{k}$ metafyzice zakládající teorii státu a práva, sepsaná formou číslovaných tezí a pokračující krok za krokem od prvotní souvislosti, jež je předpokladem pro vyvozování ostatních až po závěrečné zjištění ukazuje, že Solger pokračoval v tradici (Chr. Wolffem započaté) pojmové systematizace německé filosofie a rozvíjel ji nejen kriticky a transcendentálně v duchu kantovského kriticismu (prvořadé nejsou poznávané předměty, ale poznání toho, tak poznáváme), ale také harmonicky s idylickou světově historickou ironií, jejíž základní netriviálnost chápal zřetelně hlouběji než mnozí její odpůrci.

Přeloženo dle: Solger's Nachgelassene Schriften und Briefwechsel, herausgegeben von Ludwick Tieck und Friedrich von Raumer, 2. Band, Leipzig: Brockhaus 1826, 263-278.

\footnotetext{
${ }^{7}$ Podle mnoha německých historiků filosofie není zřejmé, zda Hegel studoval čtyřdílný dialog Erwin a Solgerovu estetiku; mínění se přiklánění k tomu, že jejich znalost byla značně omezená.

${ }^{8}$ Typicky Behler, E. (1997). Ironie und literarische Moderne, Paderborn, München: Schöningh Verlag.

${ }^{9}$ Srv. Odebrecht, R. (1925). K. W. F. Solger und die romantische Idee, in: Geisteskultur Comeniusgesellschaft, Nr. 5-6, 241-257; Heller, J. E. (1928). Solgers Philosophie der ironischen Dialektik. Ein Beitrag zur Geschichte der romantischen und spekulativ-idealistischen Philosophie. Berlin: Reuther \& Reichard.

${ }^{10}$ Steward, J. (2008), An Apostle of Irony sacrificed to Hegel's System, in: týž (edited), Kierkegaard and His German Contemporaries, Tome III Literature and Aesthetics, Burlington: Ashgate Publishing Limited, 235-270.
} 


\title{
FILOSOFIE PRÁVA A STÁTU
}

\author{
A. Základní metafyzické pojmy \\ Úvod do vědy samotné (263) \\ I
}

1. Filosofii práva a státu lze uchopit jedině prostřednictvím obecné souvislosti samotné filosofie. Tato souvislost musí tvořit úvod, lze ji ale znázornit zcela populárně a současně již jako předpoklad.

2. Středem veškerého poznání je sebevědomí, avšak jen takové sebevědomí, v kterém je obsaženo absolutní a dokonalé poznání. V takovém je současně poznatek všeobecné podstaty věcí a zároveň vědomí individua. Jestliže se říká, že celá filosofie je jen dějinami sebevědomí, pak tomu nelze rozumět z hlediska individuálního, ale pouze všeobecného. [264]

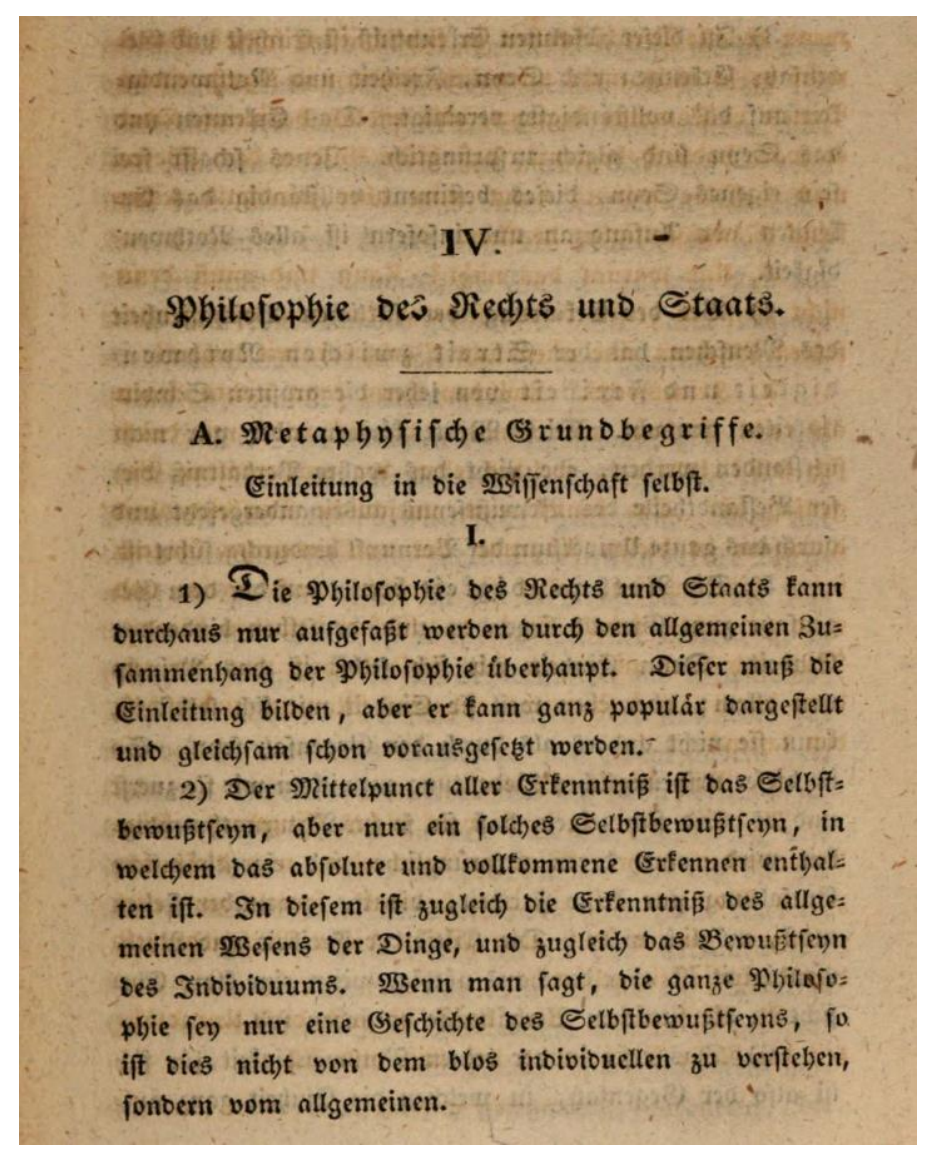

3. V tomto absolutním poznání jsou nejdokonaleji sjednoceny jednota a protiklad, poznání a bytí, svoboda a nutnost. Poznání a bytí jsou stejně původní. Poznání vytváří svobodně své vlastní bytí, bytí od začátku plně určuje poznání, a tudíž je všechno nutnost.

4. Při vysvětlování mravní uzpůsobenosti člověka působil odjakživa největší potíže spor mezi nutností a svobodou. Těmto slovům ale nelze vůbec rozumět dřív, než se rozebere skutečný vztah těchto součástí vědomí a projde celým univerzem rozumu.

5. Nutnost se zakládá na jednotě, jež tvoří základ protikladnosti a sjednocuje ji. Principem všeho je totiž jednota se sebou samým; avšak právě proto, že jednota se sebou samým jest, nemůže být jinak než skrze protiklad. Budeme ji nyní rozvíjet v tomto původním významu, až se ukáže, že se tak stává př́irodní nutností, aniž by bez jejího původního a sobě vlastního rozvinutí byla vůbec možná jí protikladná svoboda. Kritika svobody a nutnosti je však veskrze nutná, jestliže se má vytvořit jasný vhled do mravních poměrů.

6. Tím prvním v čisté nutnosti pro sebe je tedy protiklad, v kterém se zcela rozplynula jednota. [265] Ten poskytuje názor, $v$ němž se ale nazřené proměňuje plně v látku, $v$ až donekonečna dělitelnou matérii. Ta opět nemůže být bez protikladu se svou vlastní identitou - nebot' jinak by byla vším -, a touto identitou je světlo. Protiklad světla a matérie je jako protiklad času a prostoru; protikladné složky jsou tím od sebe čistě odlišeny. Názor sebe sama, jež v tom spočívá, se uskutečňuje obecnými prostředky jako organismus.

7. Zákonitost organismu je nejvyšším projevem přírodní nutnosti. Zde totiž se identita stává individualitou. Avšak s tou se současně pojí také nekonečná růinorodost. Ta je opravdově tu 
v individualitě. Nekonečně dělitelná matérie je totiž v sobě stejnorodá, poněvadž je jen identickým rozvíjejícím se proudem. Organické bytosti existují ale každá za sebe samu a nekonečně se odlišují od každé druhé. Pokud je tedy každé identická sama se sebou, má svůj princip v celém rodě a je pouze jeho výrazem. - Nutnost, která se rozvíjí až po individualitu, se nazývá príroda.

8. V celé př́ŕrodě je poznání jen odrazem matérie a právě proto se váže na obecné zákony. Každé individuum je zakořeněno v matérii, a tím je vydáno nekonečné různorodosti, avšak takové, jež je o sobě zákonitě uspořádaná a [266] a v sobě se řídí podle zákonů. Proto v př́rodě není vnitřní spor a svévole, vyjma těch, jež spočívají v individualitě. To, že se zvířata volně pohybují, má důvod $\mathrm{v}$ tom, že nutnost určuje pouze jednání individua, nikoli souvislost s ostatní př́rodou $\mathrm{v}$ celku, jako je tomu u neorganických těles. Je to tatáž nutnost, avšak jiné jsou předměty, a to pochází pouze z toho, že protiklad anorganické př́rody a organismu je nutný.

9. V tomto protikladu je predestinace jedné části pro druhé. Identita se musí nutně vztahovat na prrírodu mimo sebe, jinak by byla vším. Tento vztah jakožto plně vnější poměr je účelnost. Proto pro samotný organismus (jenž může být ve své dokonalosti pouze zvířecí) existuje dvojí vnější svět. Jednak je totiž protikladný pouhé anorganické matérii, a ta pro něj nemá jinou než neurčitou, nepojmovou účelnost, jen jako nosič. Pak ale musí být protikladný rovněž látce, která sama vyjadřuje určité pojmy, jež se vztahují na organismus jako něco identického, a sama tato látka je organická. Proto se dokonalejší zvířata neživí zemí, nýbrž rostlinami nebo zase zvířaty.

10. Svévole zviřrat se tedy nevztahuje na princip jejich pohybu, [267] poněvadž ten je dán všeobecnými zákony; nýbrž naopak, týká se nekonečně náhodné jevové různorodosti. Dotyčné zákony, pokud určují svévoli zviřrat, se nazývají instinkt. Zvířata tudíž nejsou stroje, nýbrž mají svobodnou činnost, avšak v rámci určitých př́rodních zákonů. Svobodu mít musí, protože jinak by nebyla určitými individui, čili nemohla by znázorňovat identitu př́rody. Podle toho lze určit druh poznání, jímž disponují zvíŕata.

11. Každý dotyk poznávajícího s vnějším světem je počitek. Poněvadž se celá podstata identity zvíraat zakládá na tomto dotyku, závisí jejich poznávání především na počitcích. Splynutí poznávajícího s látkou vnějšího světa je názor; rovněž ten je ve zvířatech. Jen tímto splynutím se totiž může zvíře stát něčím identickým. Celek názoru, pokud je identickým poznáním, se nazývá predstava.

12. Právě v bodě představy se člověk odlišuje od zvířete. Člověk klade své představy sám sobě jako protikladné Jednomu. Ve zvířeti je identita pouze tím, co se proměňuje do různých představ, prostřednictvím změny, jakou se mění věci.

13. V organismus jsou dva protiklady [268]: protiklad jednoho a mnohého, v němž se nachází organická bytost s vnějším světem, a protiklad opaku, který zdůvodňuje rozdíl mezi pohlavími. Oba se shodují v tom, že jsou jen úplným znázorněním všeobecné protikladnosti př́rody, bez níž by vůbec žádná prríroda nemohla být. Na nižších stupních přírody se oba tyto protiklady vzájemně směšují. Usmířeně se jeví ve světovém systému. V něm totiž existují totální individua, která jsou vzájemně propojena pomocí protikladů, jež zase vytvářejí totalitu. Ve světovém systému se uskutečnil svazek nutnosti. Na něm závisejí také ony dva protiklady a jsou jeho výrazem.

14. V systému světa se uskutečnil základ, a ten může existovat jen jakožto vztah rozumu. Tento vztah se rozvinul do obou pólů organického a anorganického světa. Teprve tím se všechno poznání stalo bytím a Bůh je v systému světa jako světová duše. Veškerý názor a veškerá látka tím přešly do pouhé existence, avšak právě do univerzální existence, a tou je přirodní univerzum. 
15. V něm se do úplné existence rozvinula nutnost, avšak právě tím se stala empirickou a ne absolutní nutností. To totiž spočívá v tom, že si jakožto nutnost neuvědomuje samu sebe, nýbrž že elementy vědomí [269] v ní existují pouze ve svých vzájemných vztazích. Tyto vztahy samotné představují svobodu, nakolik se týkají čistě individuality. Je to svoboda v přirodě (a tudíž také zlo), avšak plně podřizená nutnosti. Individualita, která není ničím dalším než výrazem nutnosti, je nejvyšší zákonitostí.

16. Ta je protikladná individualitě organických bytostí, jež je zcela náhodná, pokud je individuální. Náhoda není určována ničím. Tedy také je ničím. Pokud by měla něco být, pak by to muselo být určeno samo sebou, a tím získává bytost existenci. Jakmile je zde sebeurčení, je zde také úplně jiný svět: ideální svět.

17. Jednou z největších těžkostí je uvést ideální svět do příslušného spojení se světem fyzickým. Nestačí nahlížet fyzično jako pouhou mez, jak to dělal Fichte, protože není v žádném prípadě neurčitou mnohostí, nýbrž podléhá pevným zákonům. Hlavním bodem přitom je to, že proti bytostnému ideálnímu světu zde nestojí jenom zdání, nýbrž existence.

18. Je to príroda, která proměňuje nic nebo pouhé vznikání v existenci a činí tím z jednoty a totality jen přechod, cosi předběžného. Rozvoj existence [270], který míŕí k nekonečné různosti, zcela ruší důvod a stává se ničím oproti své jednotě. Vůči absolutní jednotě stojí v tomto rozvoji jen momentálnost a náhodnost, jež je právě jakožto protiklad pravé skutečnosti dokonalou absolutní nicotou. Avšak tím, že se di̊vod současně rozvíjí ve svůj protiklad a vyjadřuje ho v různosti, dostává svět mimo nicotu jakožto existenci. Existence, která se nerozplyne v pouhé nic, nemůže tedy být mimo prírodu. (Odtud lze čerpat rozhodující důvody proti Fichtovu idealismu.) Přírodu tudíž nelze zavrhovat a zatracovat, protože sama umožňuje, aby se ukázal pravý obsah existence. Kdyby jí nebylo, byl by jev a skutečnost hříchem. Jedině prostřednictvím př́rody lze ospravedlnit ozvláštněnost věcí.

19. V rozvíjení předmětů, které utváří příroda, není proto organismus možný bez anorganického vnějšího světa, s kterým stojí pod společným zákonem nutnosti. Proto vykazuje organický svět soustavné vznikání a zanikání, které je v existenci obsaženo jen prostřednictvím substanciality, skrze niž se vztahuje na celek organického světa. Tento celek se vyjadřuje skrze světový systém jakožto zákonité nekonečno.

20. Dokud si myslíme, že se prŕrodní [271] protiklady jen rozvíjejí pod vlivem zákona sporu, není tento zákon sám ještě ničím skutečným, ale je pouze vývojem. Ten je pak důvodem skutečnosti. Jenže, všechno musí být skutečnost, protože všechno je vztah. Musí tedy existovat nějaký bod, kde je zákon v protikladu sám sobě jakožto pouhá individualita, a tento protiklad je mezi systémem světa a člověkem. Teprve tím se dokončuje př́roda. Tím ale také upadá do dokonalého sporu sama se sebou. Člověk totiž je jednotou zákona a současně totožností se sebou samým neboli sebevědomím.

21. Protože člověk je tímto způsobem dokonalé absolutní znázornění nutnosti jakožto jednoty a současně identity se sebou samým, je v něm nejdokonalejší rozpor mezi ideálním a reálným světem a zároveň jejich souběh. A současně, poněvadž je jen náhodou vznikání a absolutní jednotou se sebou samým, můžeme na něj nahlížet jen jako na absolutní poznání, avšak v jeho existenci. Zde tedy musí začínat ideální filosofie.

22. Kde je poznání principem, tam je zprvu podstata protikladná individualitě a náhodnosti, nebo čistému vznikání. $\mathrm{Z}$ tohoto rozporu se nyní rozvíjejí tři stupně poznání, vjem, rozum a vůle. [272] 
1. První projev poznání jakožto činnosti se bezprostředně pojí s jeho vnějším omezením. Bez meze totiž neexistuje ani směr, ani činnost. Činnost je v nás daná, protože nás samotné vytváŕí, s hranicí se setkáváme jako se zárodkem skutečnosti, tedy jako s něčím okamžitým, $\mathrm{s}$ jednotlivostí. Avšak když se poznání vyjeví jen na této hranici, pak je ve zpětném ohledu stále jen něčím individuálním a konečným. Jako čisté poznání pro sebe je lze uchopit jen v protikladu vůči této hranici, a pak je čistě její negací, něčím neurčitým. Toto jsou vztahy empirického poznání, na kterých se po pravdě zakládá fichtovský idealismus.

2. Jestliže ale na poznání nahlížíme jako na absolutní poznání podstaty, pak hranice není pouhou hranicí, nýbrž absolutním bytím poznání samého nebo jeho nutností, a ta je vlastní spekulativní úvahou. Tato hodnota nutnosti se musí zachovat v celém ideálním světě a znázornit se jak v jednotlivém, tak v nejvyšším a obecném na rozličných stupních. Musíme přitom pamatovat jen na to, že skutečný stav věcí musíme zachytit nikoli v empirickém, nýbrž v absolutním vědomí.

3. Nutnost se ukazuje ve skutečném poznání vždy pozitivně jako existence nebo podmínka [273] existence; jako podstata ale negativně, nebo jako ohraničení, např́ílad v povinnosti atd. Proto je ve smyslové součásti člověka tím, co vyvolává k pozitivnímu životu instinkt; $\mathrm{v}$ rozumové je však tím, co tentýž instinkt k jednání omezuje a staví pod zákon. Proto se může v této vyšší sféře jevit také jako pouhá vnější instituce mravního života.

4. Poměr svobody a nutnosti je základ všeho poznání mravnosti a zejména práva. Je jen nezbytné, abychom ho krok za krokem odvodili.

5. Jednota se sebou samým je nutně současně jednotou protikladů, nebo sporu, na němž se jednota zakládá. Bez toho by skutečnost nebyla existencí, ale pouhým zdáním. Tato jednota protikladů se ukazuje v prŕrodě jen jako úsilí protikladů po sjednocení. Teprve v poznání je úplným sjednocením, a tam se nazývá názor. Pokud je tento názor existenciálním aktem, jehož prostřednictvím jsou poznání a bytí teprve vůbec tu, pak se nazývá produktivní názor.

6. Kdyby produktivní názor nebyl víc než bodem vzájemného průniku, pak by nebyl vůbec ničím. Činnost nebo vědomí by tím totiž zanikly. Avšak poněvadž poznání není nic jiného než akt samotného sebeztotožnění, pak musí být tento akt poznán i zde. Musí v něm být rozdíl a spor. Bod sjednocení [274] tudíž musí být sám se sebou v rozporu. Mủže však být jen dvojím: 1) výsledkem protikladu, kde se důvod nebo základ jeví jako jednota, a 2) aktem sebeztotožnění. To první je reálný, to druhé ideální význam produktivního názoru.

7. V reálném významu je produktivní názor přirodou, a sice pokud je to individuální př́roda, organické tělo. Činnost těla, v níž se všeobecný zákon nutnosti stal individuálním, se jmenuje život. To není nic jiného než tělesná, reálná myšlenka, jež se stala činnou v matérii. V těle je zákon individuální, jeho jedinečnost spadá tedy jen pod zákonitost. Zvláštní pro něj existuje jen pak, jestliže jeho zákony vyžadují totéž; je sám zvláštním, avšak v něm samotném není zvláštní, nýbrž všeobecná zákonitost. Ve své zvláštnosti je ponechán na vůli skutečnosti, a pokud je ta protikladná jeho zákonitosti, je možné, že onemocní.

8. Produktivní názor však ale nemůže být úplně tělem; je totiž aktem sebeztotožnění. Je tedy také něčím v ideálním významu a sice názorem v užším smyslu. Je otázkou, jak poznání poznává tělo samotné jako tělo. Ze současného stanoviska ho ještě nemůže poznat jako něco mimo sebe, nýbrž [275] jen jako sebe sama, nebo svou vlastní existenci. Že tato existence spadá pod zákony nutnosti ví jen ten, kdo přihlíží zvnějšku. Jako identita nebo názor v užším smyslu získává tedy celé toto stanovisko poznání ideální význam. 
9. Jakmile je názorem, dostává se rovněž do protikladu sám se sebou, a momentálnost v něm stojí v rozporu s čistým poznáním neboli jednotou. Z toho vzniká celý systém kategorií. Je to rozum podřizený názoru. Co bylo předtím zákonem přírody, je nyní zákonem myšlení, avšak je to právě tak nutné a ničím jiné než sama př́roda proměněná v poznatek. Nyní se to, co bylo $\mathrm{v}$ př́rodě protikladem identity $\mathrm{v}$ sobě samé, stalo protikladem identity a mnohosti. Tak jako př́roda dostává identitu $\mathrm{v}$ existenci, jak ji nyní dostávají kategorie a v nich se rozvíjející jednota myšlení.

10. Obojí je však současně Já, tělo a to, co je nazíráno, a tím vzniká kontakt s vnějším světem, který nazýváme počitek, z nějž se rozvíjí pudy a celá souvislost smyslovosti. Pud je sebeurčení, avšak takové, jež stojí pod zákonem smyslového počitku. Pud je nevědomé sebeutváření Já, avšak právě (276) nevědomé a nutné, které vždy vede k určité jednotlivině. Jakmile je pozdvižen do sféry reflexe, jeví se sám poznání ve dvojím světle, jednak jako pouhé zaměření na jednotlivinu, na nicotnost, a tedy jako zavrženíhodný, a jednak jako vyjádření přírodního zákona, a proto čistě a legitimně, ba jako prostředek nejkrásnějšího uspokojení.

11. Otázka zní, jak se pud pro Já stává objektivním? Prostřednictvím představivosti. To je síla, skrze niž se empirické Já samo klade a vnímá se jako svůj předmět, a skrze niž se vždy poznává jako určené jednotlivinou, jíž je právě pud. Přistihne poznání už v jednotlivém konání a jeví se proto vždy ve zvláštní podobě. Díky ní se ale vždy vnímá to, co je zákonité v uspokojení pudu, jako obecné, protože jednota poznání sebe sama se rovněž stává objektivní.

12. Avšak v pudech by bylo vznikání jakožto pouhé vznikání, jež zaniká v ničem, pokud by stávající bytí nebylo současně v jednotlivině; a skrze tento rozpor vzniká rozum. Podmínkou prijetí jevu do rozumu je systém kategorií. Ten se navzájem proniká se smyslovostí v reflexi.

13. Kategorie, myšlené jako formy skutečnosti [277], avšak ještě nevyjímají poznání z proudu, v kterém dál plyne smyslovost. Teprve abstrahující rozum fixuje obecné pojmy, je spočívají v něm, a současně pozdvihuje samotné zvláštnosti na pojmy. Abstrahující rozum však není vůbec možný bez transcendentální abstrakce; nebot' jinak by nemohl být pojem jakožto zvláštní srovnáván s čistou všeobecností, jež by pak byla doprovodným vědomím.

14. Tato čistá všeobecnost ale opět nemůže být ničím jiným než jednotou se sebou neboli sebeurčením. To zdůvodňuje jednání. Jednání se zakládá na názoru jakožto pudu, avšak na sebenázoru. Já nachází sebe sama jako jednající, tedy vždy už v průběhu určitého jednání.

Aby se takto vynacházelo, musí se odlišovat od sebe sama, jak je určeno prostřednictvím vnějších předmětů, a tak vzniká protiklad čistého sebeurčení a určení pudů zvnějšku, na kterém stojí svévole. Je to jedno a totéž Já, které kolísá mezi oběma jako svévole, a její skutečnou obecnou existencí je náhodnost.

15. Aby Já mohlo jednat, musí být ve světě účelnost. Tak jako náhled světa podle kategorií je podmínkou všeho teoretického poznání zvláštního, tak je teleologický [278] náhled podmínkou praktického. Já poznává, i když nevědomě, i v látce mimo sebe vždy jen sebe sama, tudíž se v ní poznává také rozrůzněně podle každého stupně, na kterém má jednat, jako teleologický systém. Tato účelovost je rozum podř́zený jednání.

16. Pokud je Já ve svém jednání určováno zvnějšku, nakládá s objekty, a je tudíž omezeno všeobecnou prŕírodou, která musí být všem společná právě proto, že je vnějškem. Pokud se určuje samo, musí být individuem, a tudíž omezeno nekonečnem prostřednictvím všech Já mimo sebe. To, čím je samo, vnímá mimo sebe jako svou jinakost v nekonečnu. Individualita získává také obecnost Já v existenci. 
17. Ve velmi ojedinělých projevech činnosti ve sféře smyslovosti je Já vždy jen modifikací všeobecného př́rodního zákona. Ve všeobecném čili v čisté vůli se musí současně určit jako individuum, a tím je plně individuální. Člověk je především individuum, a proto se jeho skutečná existence jeví jako předem určená jeho individualitou. Tam, kde jednáme nejčistěji, jsme nejvíc podřizeni své individualitě. Proto neexistuje dokonalá mravnost bez božské pomoci. 